\title{
Human Papillomavirus Genotypes and its Prevalence in Normal Population
}

\section{Genotip Human Papillomavirus dan Prevalensinya pada Populasi Normal}

\author{
Tofan W Utami ${ }^{1}$, Andrijono ${ }^{1}$, Laila Nuranna ${ }^{1}$, Darrell Fernando ${ }^{1}$, Alexander AW Peters ${ }^{2}$, \\ Gert J Fleuren ${ }^{3}$, Ekaterina S Jordanova ${ }^{3}$, Sigit Purbadi ${ }^{1}$ \\ ${ }^{1}$ Department of Obstetrics and Gynecology, Faculty of Medicine, University of Indonesia, Jakarta \\ ${ }^{2}$ Department of Gynecology, Leiden University Medical Center, The Netherlands \\ ${ }^{3}$ Department of Pathology, Leiden University Medical Center, The Netherlands
}

\begin{abstract}
Objective: Over 200 types of human papillomavirus (HPV) have been recognized on the basis of DNA sequence. Multiple infection is more prone to be persistent than single infection. The purpose of this study is to assess the variation of HPV types and their prevalence among negative VIA as normal population in Indonesian women.
\end{abstract}

Method: We processed cervical swabs from 1,214 patients with negative VIA. HPV DNA and its genotypes were detected using PCR based INNO-Lipa HPV DNA test. We also classified whether each infection is single or multiple.

Result: From 1,214 women with negative VIA, 39 (3.21\%) samples were positive for HPV DNA. Among them, we detected 19 types of HPV, consisting of 13 types of high-risk HPV, 5 types of low-risk HPV, and 1 type of unknown HPV (type X). The most prevalent type was HPV type $52(18.31 \%)$, followed by type 39 and X with the same proportion (9.86\%), and HPV type 16, 18, and 74 (each $8.45 \%$ ). Of the total 39 HPV-positive samples, 17 (43.6\%) showed multiple-type infection and $22(56.4 \%)$ showed single-type infection. The majority of single infection involves high-risk-HPV. The remaining were type $6,44,18,51$ and 66 , with each single-type infection showing a prevalence of $4.54 \%$.

Conclusion: Our study shows that single HPV infection among the negative VIA population are dominated by high-risk type HPV (types $52,39,16$, and 18). Single infection was more often encountered than multiple infection.

[Indones J Obstet Gynecol 2014; 4: 211-215]

Keywords: HPV DNA, HPV genotypes, multiple infection, negative VIA, single infection

\begin{abstract}
Abstrak
Tujuan: Terdapat lebih dari 200 tipe HPV yang dikenal berdasarkan sekuens DNA. Infeksi HPV multipel memiliki kecenderungan lebih untuk menjadi persisten dibandingkan dengan infeksi tunggal. Tujuan dari penelitian ini adalah untuk menilai variasi tipe HPV dan prevalensinya pada perempuan dengan IVA negatif sebagai populasi normal pada perempuan Indonesia.
\end{abstract}

Metode: Kami memeriksa apusan serviks dari 1.214 pasien dengan IVA negatif. DNA HPV dan genotipnya dideteksi dengan menggunakan tes DNA HPV INNO-Lipa berbasis PCR. Kami juga melakukan klasifikasi infeksi HPV menjadi infeksi tunggal atau multipel.

Hasil: Dari 1.214 wanita dengan IVA negatif, ditemukan 39 sampel (3,21\%) dengan DNA HPV positif. Terdeteksi 19 tipe HPV, yang terdiri dari 13 tipe HPV risiko tinggi, 5 tipe HPV risiko rendah, dan 1 tipe HPV yang belum diketahui klasifikasinya (tipe X). Tipe HPV yang paling tinggi prevalensinya adalah HPV 52 (18,31\%), diikuti tipe 39 dan X dengan proporsi yang sama (9,86\%), dan HPV tipe 16, 18, dan 74 (masing-masing 8,45\%). Dari total 39 subjek yang positif untuk DNA HPV, 17 (43,6\%) merupakan infeksi multipel, sedangkan 22 (56,4\%) subjek lainnya adalah infeksi tunggal. Infeksi tunggal didominasi oleh HPV risiko tinggi. Sisanya menunjukkan HPV tipe 6, 44, 18, 51, dan 66, dengan prevalensi masing-masing 4,54\%.

Kesimpulan: Studi ini menunjukkan bahwa infeksi HPV tunggal yang ditemukan didominasi oleh HPV risiko tinggi (HPV tipe 52, 39, 16, dan 18). Infeksi tunggal lebih sering terjadi dibandingkan infeksi multipel.

[Maj Obstet Ginekol Indones 2014; 4: 211-215]

Kata kunci: DNA HPV, genotip HPV, infeksi multipel, infeksi tunggal, IVA Negatif

Correspondence: Tofan W Utami. Department of Obstetrics and Gynecology. Faculty of Medicine University of Indonesia. Telephone: 0818859585; Email: tofanwidya@yahoo.com

\section{INTRODUCTION}

Cervical cancer is the second most common female cancer in Indonesia. ${ }^{1}$ Its incidence in Indonesia is estimated to be 100 per 100,000 population, or around 230,000 cases per year, and more than $70 \%$ of those presents to the hospital at an advanced stage. ${ }^{2}$ Development of cervical cancer due to HPV infection involves a long process. Thus, cervical cancer is a cancer that could potentially be prevented by early detection and prompt treatment of precancerous lesions. ${ }^{3}$
Persistent infection of human papillomavirus (HPV), high-risk HPV (HR-HPV) in particular, has generally been accepted as the etiology of cervical cancer. Despite this fact, there is still little knowledge on the prevalence of HPV in Indonesia. Several studies have reported the incidence of HPV infection in the general population in Indonesia, ranging from $11.4 \%$ to $25.4 \% .4,5$ The common types of HR-HPV in the population are 16, 18, 51 and 52 , but the exact prevalence varies in each study. ${ }^{4-6}$ Based on this, we conducted a study to 
assess the variation of HPV types and their prevalence among VIA-negative women as a normal population in Indonesian women.

\section{METHODS}

We performed a community-based, cross-sectional study. Sample collection was carried out at the Obstetrics and Gynecology outpatient clinic, Dr. Cipto Mangunkusumo General Hospital, Jakarta and other health facilities designated in the "See and Treat" Female Cancer Program (FCP) in Jakarta, from January to September 2012. Laboratory processing and examination were conducted at the Department of Gynecology and Department of Pathology, Leiden Universitair Medisch Centrum (LUMC), The Netherlands.

This study has been approved by the Ethics Committee of Faculty of Medicine, University of Indonesia - Dr. Cipto Mangunkusumo General Hospital. Each patient participating in this study signed an informed consent.

Patients included in this study were married women aged 20-50 years with negative VIA. Pregnant women, women with history of promiscuity, multiple partners, and intravenous drug use were excluded. After complete history-taking, a cervical swab was obtained and then inserted into a tube containing Phosphate Buffered Saline (PBS) from Gibco $^{\circledR}$. Catalog Number 10010-023). Subsequent VIA examination using 3-5\% acetic acid was conducted by trained health professionals in the particular health facilities. If the VIA result was negative, the cervical swab was then processed for detection of HPV DNA. Patient with acetowhite lesion or cervical cancer were excluded; patients with acetowhite lesion were offered cryotherapy and patients with cervical cancer were referred to the Gynecologic Oncology outpatient clinic, Dr. Cipto Mangunkusumo General Hospital.

HPV DNA examination was performed by a trained doctor and a lab technician expert in HPV. It was conducted in two steps using the INNO-LiPA HPV Genotyping Extra Kit (Fujirebio Europe). The initial step was HPV PCR (SPF10) followed by electrophoresis to detect the presence of HPV DNA. If the result was positive, it would be followed by HPV genotyping by hybridization to determine the HPV type.

The main outcome measured in this study is the HPV genotype found in VIA-negative patients. In addition, we also classified whether each infection was single or multiple. Data analysis was performed using Statistical Program for Social Sciences version 20.0 (SPSS Inc., Chicago, Illinois).

Figure 1. Flow of subjects.

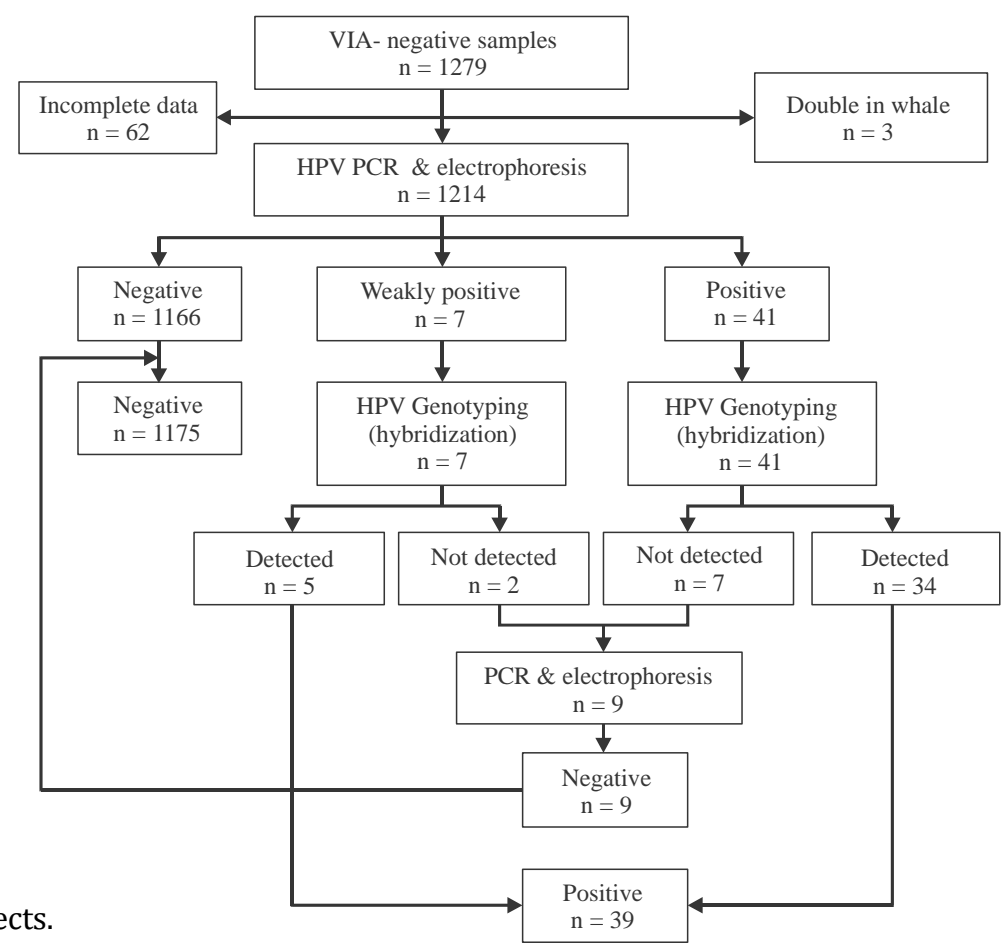




\section{RESULTS}

We obtained 1,279 VIA-negative subjects, but 65 subjects were excluded due to incomplete data. HPV DNA examination was conducted on the remaining 1,214 subjects. HPV DNA was positive in 39 (3.21\%) subjects and negative in 1175 (96.79\%) subjects (Figure 1). The mean age of the subjects in this study was 40.99 .3 years.

We found that the prevalence of HPV infection in the VIA negative group is relatively low (3.21\%). Nineteen HPV types were detected, comprising of 13 HR-HPV, 5 LR-HPV, and 1 unknown type (HPV $\mathrm{X})$. Single HPV infection was found in 22 (56.41\%) subjects, while multiple HPV infection was found in 17 subjects (43.59\%), as shown in Table 1 . The most prevalent type of HPV was HPV 52 (18.31\%). Result of HPV genotyping is shown in Table 2.

Table 1. HPV DNA Test Results

\begin{tabular}{lcc}
\hline \hline \multicolumn{1}{c}{ Variable } & n & \% \\
\hline HPV DNA (+) & 39 & 3.21 \\
HPV DNA (-) & 1175 & 96.79 \\
Types of HPV detected & & \\
HR-HPV & 13 types & \\
LR-HPV & 5 types & \\
HPV-X & 1 type & \\
Types of HPV Infection & & \\
Single infection & 22 & 56.41 \\
Multiple infection & 17 & 43.59 \\
\hline \hline
\end{tabular}

Table 2. Types of HPV Detected with HPV Genotyping

\begin{tabular}{ccc}
\hline \hline HPV Type & n (71) & \% \\
\hline HPV 52 & 13 & 18.31 \\
HPV 39 & 7 & 9.86 \\
HPV X & 7 & 9.86 \\
HPV 16 & 6 & 8.45 \\
HPV 18 & 6 & 8.45 \\
HPV 74 & 6 & 8.45 \\
HPV 44 & 3 & 4.22
\end{tabular}

\begin{tabular}{ccc} 
HPV 54 & 3 & 4.22 \\
HPV 66 & 3 & 4.22 \\
HPV 6 & 1 & 1.41 \\
HPV 31 & 1 & 1.41 \\
HPV 51 & 2 & 1.41 \\
HPV 53 & 1 & 1.41 \\
HPV 56 & 2 & 1.41 \\
HPV 58 & 2 & 1.41 \\
HPV 68 & 2 & 1.41 \\
HPV 69 & 2 & 1.41 \\
HPV 71 & 2 & 1.41 \\
HPV 73 & 2 & 1.41 \\
\hline \hline
\end{tabular}

\section{DISCUSSION}

Based on our knowledge, this is the first major study to detect HPV DNA in the normal population, defined as women who have been screened with VIA and have negative results. We found a relatively low prevalence of positive HPV DNA in negative VIA as normal population, around $3.21 \%$. Clifford et al found the range of positive HPV infection in women with normal cytology from 11 countries varied from $1.4 \%$ to $25.6 \%$ depending on the country. ${ }^{7}$ Our finding is on the lower end of that range. Therefore in our study, VIA is comparable to Pap test, and may even give better results. However, it is important to note that VIA is unable to detect lesions in the endocervix. ${ }^{8}$

Among 1,214 VIA-negative subjects in this study, we detected 39 subjects (3.21\%) with positive HPV DNA and performed hybridization technique for genotyping examination. Nineteen types of HPV were detected, namely HPV types $6,16,18,31,39$, $44,51,52,53,54,56,58,66,68,69,71,73,74$, and one of unknown type (HPV X). When classified, there were 13 types (68.42\%) HR-HPV, namely types $16,18,31,39,51,52,56,58,66,68,69,71$, and 73; while 5 types of LR-HPV were detected (26.32\%), HPV types $6,44,53,54$, and 74. HPV X (5.26\%) is an unknown HPV type classification.

The most frequent type of HPV detected were type $52(18.31 \%)$, followed by type 39 and $\mathrm{X}$ with the same proportion (9.86\%), and HPV type 16,18 , and 74 (each $8.45 \%$ ). In a large scale study in the general population in three major cities in Indone- 
sia, Vet et al also reported similar results; where the most commonly detected type of HPV was type $52(23.2 \%)$, followed by HPV type 16 (18.0\%), 18 (16.1\%), and $39(11.8 \%){ }^{5}$ Even though the prevalence of HPV infection in women with negative VIA is relatively low $(3.21 \%)$, but most $(68.42 \%)$ were infected by HR-HPV. This is an important fact for clinicians in considering the management of patients with negative VIA.

Clifford et al reported that even though the overall prevalence of HPV in general and HPV 16 was the highest in sub-Saharan Africa, the population in Europe infected with HPV had higher chances of being infected with HPV $16 .{ }^{7}$ In a study conducted by Tabora et al in a population with normal cytology, 23 HPV types were detected, the most frequent types being HPV 16, 51, 31, 18, and $11 .{ }^{9}$ Another study on 1,859 women with normal cytology detected 32 different HPV types, including HPV type X $(0.4 \%){ }^{10}$

This research also consistently supports previous data that states HPV types 16 and 18 as HRHPV is apparently common in the asymptomatic general population with the same proportion of the population suffering from cervical cancer. HR-HPV type 52 and 39 were the most-commonly identified type, both in population with negative VIA and a general population who has not been screened, thus they should get special attention.

The proportion of single and multiple HPV infection in our study was comparable. This finding is not of significant importance, and other studies have reported conflicting significance of single or multiple HPV infections. Cuschieri et al found that multiple HR-HPV infection is not more common in high-grade squamous intraepithelial lesions (HSIL) than in low-grade squamous intraepithelial lesions (LSIL). ${ }^{11}$ Goodman et $\mathrm{al}^{12}$ and Campos et al ${ }^{13}$ reported that persistence of HPV infection was not significantly different between single and multiple HPV infections. Trottier et al showed that multiple HR- HPV infection increases the incidence of precancerous lesions within 4 years of monitoring. ${ }^{14}$ In contrast, Cuschieri et al showed that multiple HPV infection do not lead to a higher risk of precancerous lesion within 2-3 years of monitoring, compared to single infection of HR-HPV. ${ }^{15}$

\section{CONCLUSION}

Our study may add a new insight to the prevalence of HPV in women, as we have previously screened the subjects with VIA. Despite the low prevalence (3.21\%), most of the positive cases were infected by high-risk HPV, particularly HPV 52, 39, 16, and 18. However, this fact should not inhibit the use of VIA for widespread screening in Indonesia or other countries with low resource settings, as it is still the easiest and cheapest method of screening available.

\section{ACKNOWLEDGEMENT}

This research is supported by the Department of Obstetrics and Gynecology, Faculty of Medicine, University of Indonesia, Jakarta, Indonesia; the Department of Gynecology, Leiden University Medical Center, The Netherlands; and the Department of Pathology, Leiden University Medical Center, The Netherlands.

\section{REFERENCES}

1. Ministry of Health of the Republic of Indonesia. Histopathological data of cancer in Indonesia. Jakarta: Ministry of Health of the Republic of Indonesia; 2006.

2. Aziz MF. Problems in cervical cancer. Cermin Dunia Kedokteran 2001; 133: 5-7.

3. Au WW, Abdou-Salama S, Sierra-Torres $\mathrm{CH}$, et al. Environmental risk factors for prevention and molecular intervention of cervical cancer. Int J Hygiene Environ Health 2007; 210(6): 671-8.

4. Garland SM, Cuzick J, Domingo EJ, et al. Recommendations for cervical cancer prevention in Asia Pacific. Vaccine 2008; 19(26 Suppl 12): 89-98.

5. Vet JN, de Boer MA, van den Akker BE, et al. Prevalence of human papillomavirus in Indonesia: a population-based study in three regions. Bri J Cancer 2008; 99(1): 214-8.

6. Domingo EJ, Noviani R, Noor MR, et al. Epidemiology and prevention of cervical cancer in Indonesia, Malaysia, the Philippines, Thailand and Vietnam. Vaccine 2008; 26 Suppl 12: 71-9.

7. Clifford GM, Gallus S, Herrero R, et al. Worldwide distribution of human papillomavirus types in cytologically normal women in the International Agency for Research on Cancer HPV prevalence surveys: a pooled analysis. Lancet 2005; 366(9490): 991-8.

8. Sankaranarayanan R, Rajkumar R, Theresa R, et al. Initial results from a randomized trial of cervical visual screening in rural South India. Int J Cancer J 2004; 109(3): 461-7.

9. Tabora N, Bakkers JM, Quint WG, et al. Human papillomavirus infection in Honduran women with normal cytology. Cancer Causes Control 2009; 20(9): 1663-70.

10. Molano M, Posso H, Weiderpass E, et al. Prevalence and determinants of HPV infection among Colombian women with normal cytology. Bri J Cancer 2002; 87(3): 324-33. 
11. Cuschieri KS, Cubie HA, Whitley MW, et al. Multiple high risk HPV infections are common in cervical neoplasia and young women in a cervical screening population. J Clin Pathol 2004; 57(1): 68-72.

12. Goodman MT, Shvetsov YB, McDuffie K, et al. Prevalence, acquisition, and clearance of cervical human papillomavirus infection among women with normal cytology: Hawaii Human Papillomavirus Cohort Study. Cancer Res 2008; 68(21): 8813-24.
13. Campos NG, Rodriguez AC, Castle PE, et al. Persistence of concurrent infections with multiple human papillomavirus types: a population-based cohort study. J Infect Dis 2011; 203(6): 823-7.

14. Trottier H, Mahmud S, Costa MC, et al. Human papillomavirus infections with multiple types and risk of cervical neoplasia. Cancer Epidemiol Biomarkers Prev 2006; 15(7): 1274-80.

15. Cuschieri KS, Cubie HA, Whitley MW, et al. Persistent high risk HPV infection associated with development of cervical neoplasia in a prospective population study. J Clin Pathol 2005; 58(9): 946-50. 